\title{
STUDI INDEGENOUS PENYALAHGUNAAN NARKOBA PADA MAHASISWA/I STIKBA JAMBI
}

\author{
Muhammad Hidayat \\ Program studi D 3 Keperawatan STIKes Baiturrahim Jambi \\ Email : hidayat.immunologyst82@yahoo.com
}

\begin{abstract}
The tendency to increase the use of addictive substances among young people allegedly in line with increasing pressure in all areas of life including students.The study was conducted with the aim to find out how the description of drug abuse in students STIKBA Jambi.Sampling technique used is non-random sampling technique with data collection tool in the form of open-ended questionnaire.It is known that according to the STIKBA students' admission they never use drugs (99\%), the reason never to abuse drugs (46\%), the effect of never using drugs is to stay healthy (98\%), knowledge of where and how acquisition of drugs is not know (85\%), source of income is still from parents (99\%), the positive effect of never using drugs is body remain healthy (49\%), knowledge of drug type is shabu-shabu $(24,2 \%)$.According to the STIKBA students' admission they never use drugs (99\%) and those who have used drugs (1\%) factors causing previous drug abuse is due to social factors, this is based on the conclusions of direct interviews from the informant who stated that the association factor with peers that are too free and uncontrolled cause the students get involved in doing drugs drug misuse.
\end{abstract}

Keywords: Drug abuse, STIKBA students

\begin{abstract}
ABSTRAK
Kecenderungan meningkatnya penggunaan zat adiktif di kalangan kaum muda diduga sejalan dengan meningkatnya tekanan dalam segala bidang kehidupan termasuk juga mahasiswa/I. Tujuan penelitian ini untuk mengetahui bagaimana gambaran penyalahgunaan narkoba pada mahasiswa/I STIKBA Jambi.Teknik pengambilan sampling yang digunakan adalah teknik non random sampling dengan alat pengumpul data berupa open-ended questionnaire. Diketahui bahwa menurut pengakuan mahasiswa/I STIKBA adalah mereka tidak pernah menggunakan narkoba (99\%), alasan tidak pernah menyalahgunakan narkoba karena berbahaya (46\%), dampak tidak pernah menggunakan narkoba adalah tetap sehat (98\%), pengetahuan dimana dan cara memperoleh narkoba adalah tidak tahu (85\%), sumber penghasilan masih dari orang tua (99\%), dampak positif tidak pernah menggunakan narkoba adalah tubuh tetap sehat (49\%), pengetahuan tentang jenis narkoba adalah sabu-sabu (24,2 \%). Menurut pengakuan mahasiswa/I STIKBA adalah mereka tidak pernah menggunakan narkoba (99\%) dan mereka yang pernah menggunakan narkoba (1\%) faktor yang menyebabkan terjadinya penyalahgunaan narkoba sebelumnya adalah disebabkan karena faktor pergaulan, hal ini didasarkan pada kesimpulan dari hasil wawancara langsung dari informan yang menyatakan bahwa faktor pergaulan dengan teman sebaya yang terlalu bebas dan tidak terkontrol menyebabkan mahasiswa ikut terjerumus melakukan penyalah gunaan narkoba narkoba.
\end{abstract}

Kata Kunci: Penyalahgunaan narkoba, mahasiswa/I STIKBA. 


\section{PENDAHULUAN}

Generasi muda sebagai generasi penerus pembangunan bangsa diharapkan memiliki kepribadian yang mantap serta berbudi pekerti luhur, terampil serta mampu menguasai ilmu pengetahuan dan teknologi. Lebih-lebih dalam menghadapi era global, generasi muda dituntut memiliki keunggulan kompetitif pada persaingan antar bangsa di segala bidang kehidupan. Generasi muda yang tangguh dan bermutu unggul, sehat jasmani dan rohani, merupakan prasyarat mutlak bagi masa depan bangsa. Oleh karena itu, kebijakan bagi masa depan generasi muda senantiasa memperoleh perhatian yang besar.

Terwujudnya generasi muda yang berkemampuan unggul, sehat lahir dan batin, merupakan tanggungjawab bersama antara orangtua, masyarakat, dan pemerintah. Lembaga pendidikan memiliki peran yang strategis dalam mengarahkan, menciptakan iklim yang kondusif, mensosialisasikan nilai dan norma kehidupan bagi terbentuknya manusia Indonesia yang berakhlak serta berkepribadian.

Semua orang yakin dirinya tidak akan pernah menyalahgunakan narkoba. Namun kenyataannya, hampir semua orang pernah menerima tawaran salah satu jenis narkoba. Penawaran terjadi dalam kehidupan sehari-hari, pada setiap waktu dan di setiap tempat. Awalnya menolak. Karena bujukan, ingin tahu, ingin mencoba, apalagi gratisan, akhirnya mau menerima, dan pemakaiannya berlanjut. Itu sebabnya orang tidak siap, ketika menghadapi situasi penawaran narkoba. Orang harus terampil berkata tidak ! Jika tidak, meskipun tahu bahaya narkoba, belum tentu mampu menolaknya. Perlu sikap percaya diri, agar mampu menolak tekanan kelompok sebaya.

Kecenderungan meningkatnya penggunaan zat adiktif di kalangan kaum muda diduga sejalan dengan meningkatnya tekanan dalam segala bidang kehidupan. Kaum muda yang tidak mampu menghadapinya dapat dengan mudah melarikan diri, memperoleh kenikmatan dan ketenangan dengan menggunakan obat (zat) tersebut.

Gejala penyalahgunaan narkoba telah mulai merebak sejak 30 tahun yang lalu. Menurut Hawari (1991), berkembanganya penyalahgunaan obat dan narkotika terutama diawali sekitar tahun 1969, yang ditandai dengan beberapa remaja mulai datang berobat ke lembaga Kesehatan Jiwa. Pada tahun 1975 pengguna narkoba diperkirakan baru sekitar 5 ribu orang, tetapi pada tahun 2004 pengguna narkoba sudah mencapai sekitar 3 juta dengan mayoritas pengguna remaja. Jumlah kasus tindak pidana narkoba juga mengalami peningkatan dari tahun ke tahun di kota Jambi seperti tampak pada tabel berikut.

Tabel 1. Jumlah Kasus Narkoba di kota Jambi tahun 2015 s.d. 2016

\begin{tabular}{cllll}
\hline \multirow{2}{*}{ Jenis } & \multicolumn{4}{c}{ Kasus Narkoba } \\
\cline { 2 - 5 } Kelamin & Rawat & Rawat & Rawat & Rawat \\
& Inap & Inap & Jalan & Jalan \\
& 2015 & 2016 & 2015 & 2016 \\
\hline Laki-laki & 28 & 32 & 9 & 26 \\
\hline Perempuan & 2 & 1 & 1 & 0 \\
\hline & 30 & 33 & 10 & 26 \\
\hline
\end{tabular}

Sumber: BNN kota Jambi, 2017

Berdasarkan uraian di atas, fenomena pada saat ini menunjukkan bahwa kejadian penyalahgunaan narkoba meningkat. BNN kota Jambi, 2017 menjelaskan pula bahwa terdapat 3 orang diantaranya adalah mahasiswa. Pendidikan merupakan salah satu pihak yang berkewajiban dan bertanggung jawab dalam upaya pencegahan penyalahgunaan narkoba dikalangan remaja yang berstatus mahasiswa. Karena remaja merupakan objek yang secara emosional masih labil, sehingga sangat rentan untuk menggunakan narkoba. Mulai dari rasa ingin tahu, mau cobacoba, ikut-ikutan teman, rasa solidaritas grup yang kuat dan memilih lingkungan yang salah sampai dengan faktor keluarga yang kurang perhatian dan lain 
sebagainya. Disamping dari objek sasarannya yang labil, sekolah dan kampus yang menjadi tempat yang rentan untuk peredaran narkoba.

Salah satu aspek penting yang perlu dilakukan adalah pencegahan (preventif) penyalahgunaan narkoba, serta pelaksanaan berbagai langkah bekerjasama dengan beberapa instansi terkait untuk melakukan pembinaan mahasiswa agar mengetahui dan menyadari bahaya penyalahgunaan dan pemakaian narkoba.

Berdasarkan uraian tersebut diatas maka rumusan masalahnya adalah bagaimana gambaran penyalahgunaan narkoba pada mahasiswa/I STIKBA Jambi.

\section{METODE PENELITIAN}

Penelitian ini menggunakan pendekatan kualitatif. Penelitian kualitatif merupakan suatu penelitian yang mendalam (in-depth), berorientasi pada kasus dari sejumlah kecil kasus, termasuk satu studi kasus (Morissan, 2012: 22

Subjek dalam penelitian ini berjumlah 701 mahasiswa Sekolah Tinggi Ilmu Kesehatan Baiturrahim Jambi (STIKBA), berasal dari 5 program studi reguler yang berbeda, yaitu program studi D3 Keperawatan, Program studi D3 Kebidanan, Program studi D3 fisioterafi, Program Studi S1 Keperawatan, dan Program Studi S1 Gizi. Teknik pengambilan sampling yang digunakan adalah teknik non random sampling. Jenis sampel ini tidak dipilih secara acak. Tidak semua unsur atau elemen populasi mempunyai kesempatan yang sama untuk dipilih menjadi sampel. Unsur populasi yang terpilih menjadi sampel bisa disebabkan karena kebetulan atau karena faktor lain yang sebelumnya sudah direncanakan oleh peneliti.

Penelitian ini menggunakan instrument berupa kuesioner dengan pertanyaan terbuka. Setiap subjek diminta untuk menjawab pertanyaan dengan jujur yang terdiri dari 10 pertanyaan. Pertanyaan-pertanyaan yang diajukan adalah sebagai berikut:

1. Apakah anda pernah menggunakan narkoba ?

2. Alasan menggunakan atau tidak menggunakan narkoba?

3. Dampak menggunakan atau tidak menggunakan narkoba?

4. Keinginan menggunakan atau tidak menggunakan narkoba?

5. Dimana memperoleh narkoba ?

6. Bagaimana mempereoleh narkoba ?

7. Sumber keuangan dan keuangan yang diperoleh dipergunakan untuk narkoba atau tidak dipergunakan untuk narkoba?

8. Dampak positif dan negative menggunakan atau tidak menggunakan narkoba?

9. Jenis narkoba yang digunakan atau jenis narkoba yang diketahui ?

10.Apakah sedang menggunakan narkoba?

\section{HASIL DAN PEMBAHASAN}

Temuan penelitian adalah hasil yang didapatkan dari sebuah penelitian yang telah dilakukan oleh peneliti, baik dengan menggunakan metode observasi, wawancara maupun dengan metode survei. Dalam hal ini, temuan penelitian yang didapatkan oleh peneliti yaitu berupa jawaban-jawaban dari para responden. Terdapat 10 pertanyaan yang harus di jawab oleh responden penelitian.

1. Soal no. 1 (Apakah anda pernah menggunakan narkoba ?)

Pada soal nomor satu dilakukan proses koding tahap satu dan didapatkan 3 kategori yang diambil dari hasil jawaban responden. Untuk memberikan gambaran secara lebih mudah, peneliti menyajikan hasil koding tahap satu dalam bentuk tabel sebagai berikut: 
Tabel 1 Apakah anda pernah menggunakan narkoba?

\begin{tabular}{llcc}
\hline NO & Kategori & $\begin{array}{c}\text { Frekuensi } \\
\text { Pengakuan }\end{array}$ & $\%$ \\
\hline 1. & Tidak Pernah & 694 & 99 \\
\hline 2. & Pernah & 6 & 0,9 \\
\hline 3. & $\begin{array}{l}\text { Kadang- } \\
\text { kadang }\end{array}$ & 1 & 0,1 \\
\hline & Total & 701 & $\begin{array}{c}100 \\
\%\end{array}$ \\
\hline
\end{tabular}

Kelompok yang terkategorisasikan berada pada urutan nomor 1 sampai 3, selanjutnya koding tahap dua dilakukan untuk mengelompokkan kategorikategori yang spesifik ke dalam satu kategori umum, untuk lebih mudah dipahami, peneliti menyajikannya dalam bentuk tabel sebagai berikut:

Tabel 2 Koding tahap 2, soal nomor 1

\begin{tabular}{cccc}
\hline NO & Kategori & $\begin{array}{c}\text { Frekuensi } \\
\text { Pengakuan }\end{array}$ & $\%$ \\
\hline 1. & Tidak & 694 & 99 \\
& Pernah & & \\
\hline 2. & Pernah & 7 & 1 \\
\hline & Total & 701 & $\begin{array}{c}100 \\
\%\end{array}$
\end{tabular}

Lanjutan koding tahap 2, soal nomor 1

Berdasarkan tabel di atas, diketahui bahwa kategori tidak pernah memiliki skor tertinggi yaitu sebesar $99 \%$ dengan responden sebanyak 694 orang.

2. Soal no. 2 (Alasan menggunakan atau tidak menggunakan narkoba ?)

Pada soal nomor dua dilakukan proses koding tahap satu dan didapatkan 15 kategori yang diambil dari hasil jawaban responden. Peneliti mengelompokkan jawaban responden ke dalam dua kelompok, yaitu kelompok yang terkategorisasi sebanyak 700 jawaban dan sebanyak 1 jawaban yang tidak terkategorisasikan. Untuk memberikan gambaran secara lebih mudah, peneliti menyajikan hasil koding tahap satu dalam bentuk tabel sebagai berikut:
Tabel 3 Koding tahap 1, soal nomor 2

\begin{tabular}{|c|c|c|c|c|}
\hline \multirow[b]{2}{*}{ Alasan } & \multicolumn{3}{|c|}{ Kategori } & \multirow[b]{2}{*}{$\%$} \\
\hline & $\begin{array}{l}\text { Tidak } \\
\text { Pernah }\end{array}$ & $\begin{array}{l}\text { Pern } \\
\text { ah }\end{array}$ & $\begin{array}{l}\text { Kadan } \\
\text { g- } \\
\text { kadan } \\
\text { g }\end{array}$ & \\
\hline Berbahaya & 90 & - & - & 13 \\
\hline $\begin{array}{l}\text { Bisa } \\
\text { ketergantungan/ } \\
\text { kecanduan }\end{array}$ & 18 & - & - & 3 \\
\hline $\begin{array}{l}\text { Dapat } \\
\text { menghancurkan } \\
\text { kehidupan dan } \\
\text { kesehatan }\end{array}$ & 98 & - & - & 14 \\
\hline $\begin{array}{l}\text { Merusak masa } \\
\text { depan }\end{array}$ & 38 & - & - & 5 \\
\hline $\begin{array}{l}\text { Tidak } \\
\text { bermanfaat }\end{array}$ & 78 & - & - & 11 \\
\hline Haram & 168 & - & - & 24 \\
\hline $\begin{array}{l}\text { Tidak baik } \\
\text { untuk } \\
\text { dikonsumsi }\end{array}$ & 8 & - & - & 1 \\
\hline $\begin{array}{l}\text { Dapat merusak } \\
\text { diri dan orang } \\
\text { lain }\end{array}$ & 58 & - & - & 8 \\
\hline $\begin{array}{l}\text { Merusak sosial, } \\
\text { budaya, mental }\end{array}$ & 20 & - & - & 3 \\
\hline Rugi & 28 & - & - & 4 \\
\hline $\begin{array}{l}\text { Tidak } \\
\text { ingin/tidak } \\
\text { tertarik }\end{array}$ & 90 & - & - & 13 \\
\hline Coba-coba & - & 3 & - & $\begin{array}{l}0 \\
4\end{array}$ \\
\hline $\begin{array}{l}\text { Cuma Ingin } \\
\text { tahu }\end{array}$ & - & 2 & - & $\begin{array}{l}0, \\
3\end{array}$ \\
\hline $\begin{array}{l}\text { Mengimbangi } \\
\text { Kawan }\end{array}$ & - & - & 1 & $\begin{array}{c}0 \\
1\end{array}$ \\
\hline $\begin{array}{l}\text { Tidak } \\
\text { dijelaskan }\end{array}$ & - & 1 & - & $\begin{array}{c}0 \\
1\end{array}$ \\
\hline $\begin{array}{l}\text { Selanju } \\
\text { dilakukan ur } \\
\text { kategori- katego } \\
\text { satu kategori u } \\
\text { dipahami, pene } \\
\text { bentuk tabel seb }\end{array}$ & $\begin{array}{l}\text { nya koc } \\
\text { tuk n } \\
\text { i yang } \mathrm{s} \\
\text { lum, unt } \\
\text { ti meny } \\
\text { gai beril }\end{array}$ & $\begin{array}{l}\text { ng t } \\
\text { engelc } \\
\text { esifik } \\
\text { lk leb } \\
\text { jikann } \\
\text { ut: }\end{array}$ & $\begin{array}{l}\text { Iap dua } \\
\text { npokkan } \\
\text { e dalam } \\
\text { mudah } \\
\text { a dalam }\end{array}$ & \\
\hline
\end{tabular}


Tabel 4 Koding tahap 2, soal nomor 2

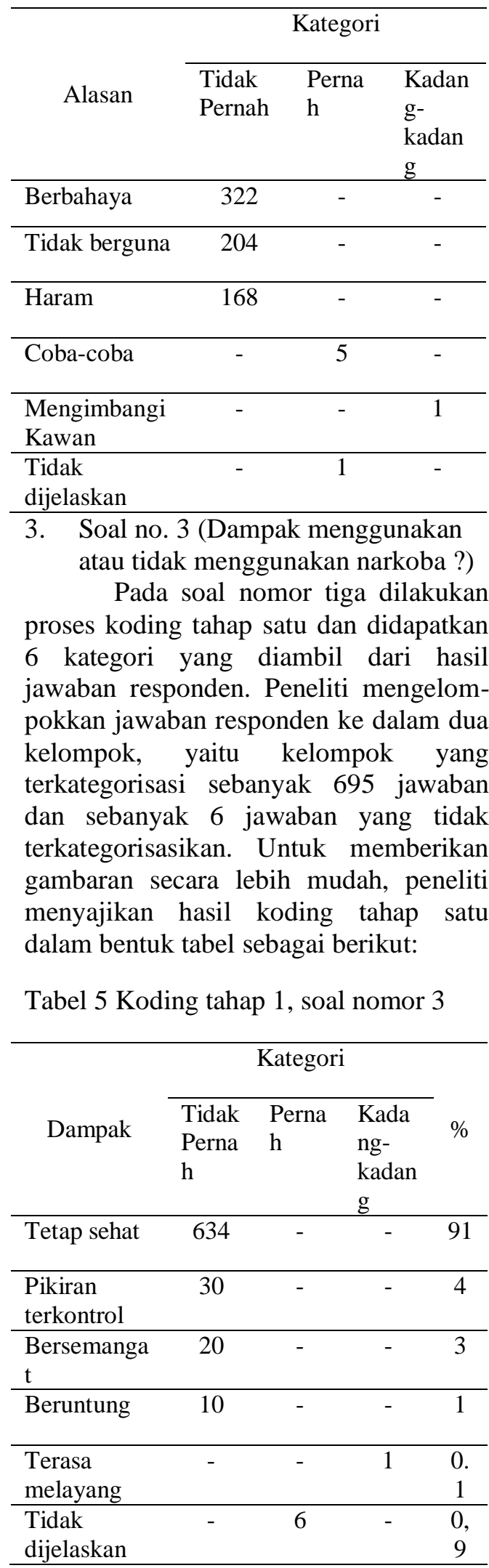

Selanjutnya koding tahap dua dilakukan untuk mengelompokkan kategorikategori yang spesifik ke dalam satu kategori umum, untuk lebih mudah dipahami, peneliti menyajikannya dalam bentuk tabel sebagai berikut:

Tabel 6 Koding tahap 2, soal nomor 3

\begin{tabular}{|c|c|c|c|}
\hline \multirow[b]{2}{*}{ Alasan } & \multicolumn{2}{|c|}{ Kategori } & \multirow[b]{2}{*}{$\%$} \\
\hline & $\begin{array}{ll}\text { Tidak } & \text { Perna } \\
\text { Perna } & \mathrm{h} \\
\mathrm{h} & \\
\end{array}$ & $\begin{array}{l}\text { Kadan } \\
\text { g- } \\
\text { kadang }\end{array}$ & \\
\hline $\begin{array}{l}\text { Tetap } \\
\text { sehat }\end{array}$ & 684 & - & 98 \\
\hline $\begin{array}{l}\text { Berun- } \\
\text { tung }\end{array}$ & 10 & - & 1 \\
\hline $\begin{array}{l}\text { Terasa } \\
\text { melayang }\end{array}$ & - & 1 & $\begin{array}{c}0, \\
1\end{array}$ \\
\hline $\begin{array}{l}\text { Tidak } \\
\text { dijelaskan }\end{array}$ & - & - & $\begin{array}{l}0, \\
9\end{array}$ \\
\hline \multirow{2}{*}{\multicolumn{4}{|c|}{$\begin{array}{l}\text { 4. Soal no. } 4 \text { (Keinginan menggunakan } \\
\text { narkoba ?) } \\
\text { Pada soal nomor empat dilakukan proses } \\
\text { koding tahap satu dan didapatkan } 5 \\
\text { kategori yang diambil dari hasil jawaban } \\
\text { responden. Peneliti mengelompokkan } \\
\text { jawaban responden ke dalam dua } \\
\text { kelompok, yaitu kelompok yang } \\
\text { terkategorisasi sebanyak } 700 \text { jawaban } \\
\text { dan sebanyak } 1 \text { jawaban yang tidak } \\
\text { terkategorisasikan. Untuk memberikan } \\
\text { gambaran secara lebih mudah, peneliti } \\
\text { menyajikan hasil koding tahap satu } \\
\text { dalam bentuk tabel sebagai berikut: } \\
\text { Tabel } 7 \text { Koding tahap 1, soal nomor } 4\end{array}$}} \\
\hline & & & \\
\hline \multirow[b]{2}{*}{ Keinginan } & \multicolumn{2}{|c|}{ Kategori } & \\
\hline & $\begin{array}{ll}\text { Tidak } & \text { Perna } \\
\text { Perna } & \mathrm{h} \\
\mathrm{h} & \\
\end{array}$ & $\begin{array}{l}\text { Kadang } \\
\text {-kadang }\end{array}$ & $\%$ \\
\hline $\begin{array}{l}\text { Tidak } \\
\text { disebutkan }\end{array}$ & 1 & - & $\begin{array}{c}0, \\
1 \\
\end{array}$ \\
\hline $\begin{array}{l}\text { Tergantun } \\
\text { g situasi }\end{array}$ & - & 1 & $\begin{array}{c}0, \\
1\end{array}$ \\
\hline $\begin{array}{l}\text { Sudah } \\
\text { berhenti }\end{array}$ & 5 & - & $\begin{array}{l}0, \\
8\end{array}$ \\
\hline Tidak & 594 & - & 85 \\
\hline $\begin{array}{l}\text { Tidak } \\
\text { akan } \\
\text { pernah }\end{array}$ & 100 & - & 14 \\
\hline
\end{tabular}


Selanjutnya koding tahap dua dilakukan untuk mengelompokkan kategorikategori yang spesifik ke dalam satu kategori umum, untuk lebih mudah dipahami, peneliti menyajikannya dalam bentuk tabel sebagai berikut:

Tabel 8 Koding tahap 2, soal nomor 4

\begin{tabular}{|c|c|c|c|c|}
\hline \multirow[b]{2}{*}{ Alasan } & \multicolumn{3}{|c|}{ Kategori } & \multirow[b]{2}{*}{$\%$} \\
\hline & $\begin{array}{l}\text { Tidak } \\
\text { Perna } \\
\text { h }\end{array}$ & $\begin{array}{l}\mathrm{Pe} \\
\mathrm{rn} \\
\mathrm{ah}\end{array}$ & $\begin{array}{l}\text { Kadan } \\
\text { g- } \\
\text { kadan } \\
\text { g }\end{array}$ & \\
\hline $\begin{array}{l}\text { Tidak } \\
\text { disebutkan }\end{array}$ & - & 1 & - & 0,1 \\
\hline $\begin{array}{l}\text { Tergantung } \\
\text { situasi }\end{array}$ & - & & 1 & 0,1 \\
\hline $\begin{array}{l}\text { Sudah } \\
\text { berhenti }\end{array}$ & - & 5 & & 0,8 \\
\hline Tidak ingin & 694 & - & - & 99 \\
\hline \multicolumn{5}{|c|}{$\begin{array}{l}\text { Pada soal nomor lima dilakukan proses } \\
\text { koding dan didapatkan } 4 \text { kategori yang } \\
\text { diambil dari hasil jawaban responden. } \\
\text { Peneliti mengelompokkan jawaban } \\
\text { responden ke dalam dua kelompok, yaitu } \\
\text { kelompok yang terkategorisasi sebanyak } \\
695 \text { jawaban dan sebanyak } 6 \text { jawaban } \\
\text { yang tidak terkategorisasikan. Untuk } \\
\text { memberikan gambaran secara lebih } \\
\text { mudah, peneliti menyajikan hasil koding } \\
\text { tahap satu dalam bentuk tabel sebagai } \\
\text { berikut: }\end{array}$} \\
\hline \multicolumn{5}{|c|}{ Tabel 9 Koding tahap 1 , soal nomor 4} \\
\hline \multirow{2}{*}{$\begin{array}{c}\text { Tempat } \\
\text { memperoleh } \\
\text { narkoba }\end{array}$} & \multicolumn{3}{|c|}{ Kategori } & \\
\hline & $\begin{array}{l}\text { Tidak } \\
\text { Perna } \\
\mathrm{h}\end{array}$ & $\begin{array}{l}\text { Perna } \\
\mathrm{h}\end{array}$ & $\begin{array}{l}\text { Kada } \\
\text { ngka } \\
\text { dang }\end{array}$ & $\%$ \\
\hline $\begin{array}{l}\text { Tidak } \\
\text { disebut kan }\end{array}$ & - & 6 & - & 0,9 \\
\hline Sama teman & - & - & 1 & 0,1 \\
\hline Tidak tahu & 594 & - & - & 85 \\
\hline $\begin{array}{l}\text { Bandar } \\
\text { narkoba }\end{array}$ & 100 & - & - & 14 \\
\hline
\end{tabular}

6. Soal no. 6 (Bagaimana cara memperoleh narkoba?)

Pada soal nomor enam dilakukan proses koding dan didapatkan 4 kategori yang diambil dari hasil jawaban responden. Peneliti mengelompokkan jawaban responden ke dalam dua kelompok, yaitu kelompok yang terkategorisasi sebanyak 695 jawaban dan sebanyak 6 jawaban yang tidak terkategorisasikan. Untuk memberikan gambaran secara lebih mudah, peneliti menyajikan hasil koding tahap satu dalam bentuk tabel sebagai berikut:

Tabel 10 Koding tahap 1, soal nomor 4

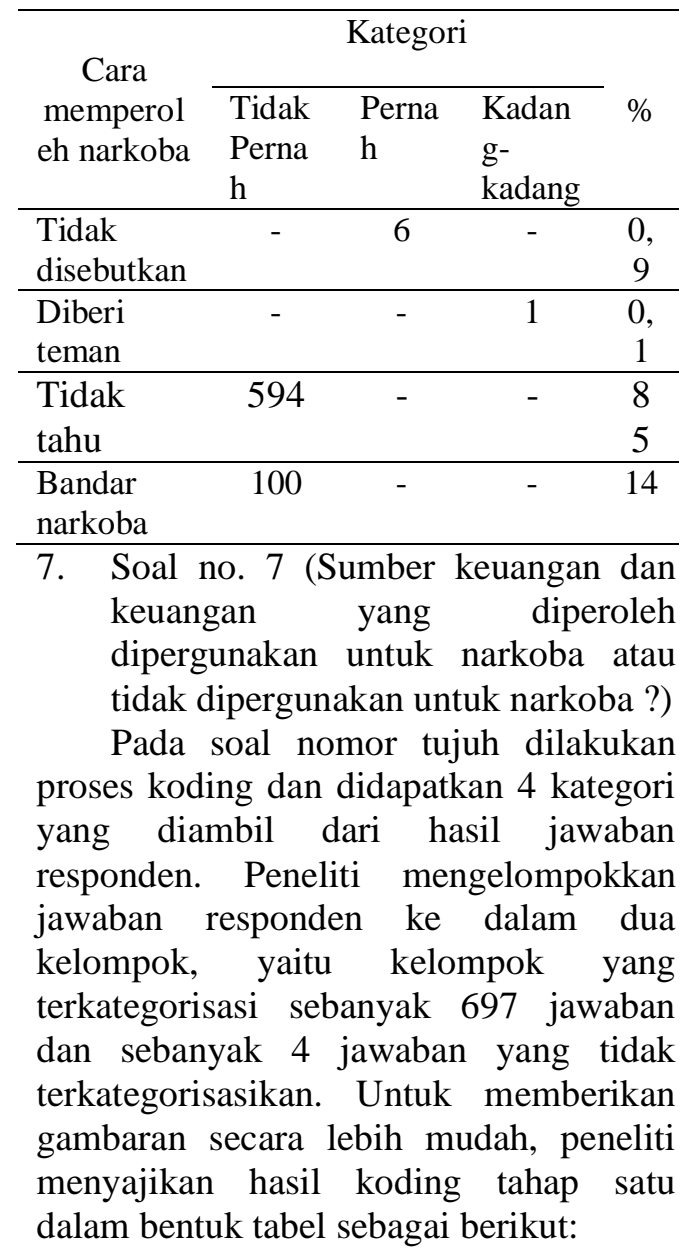


Tabel 11 Koding tahap 1, soal nomor 7

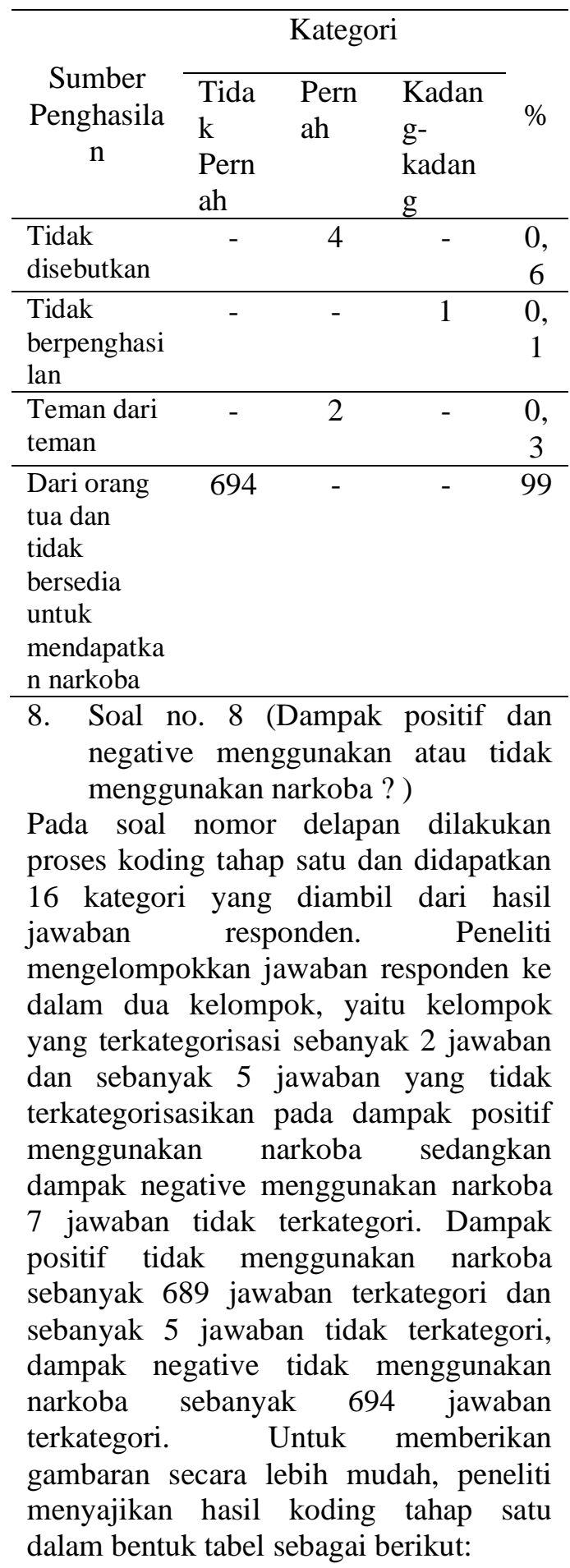

Tabel 12 Koding tahap 1, soal nomor 8

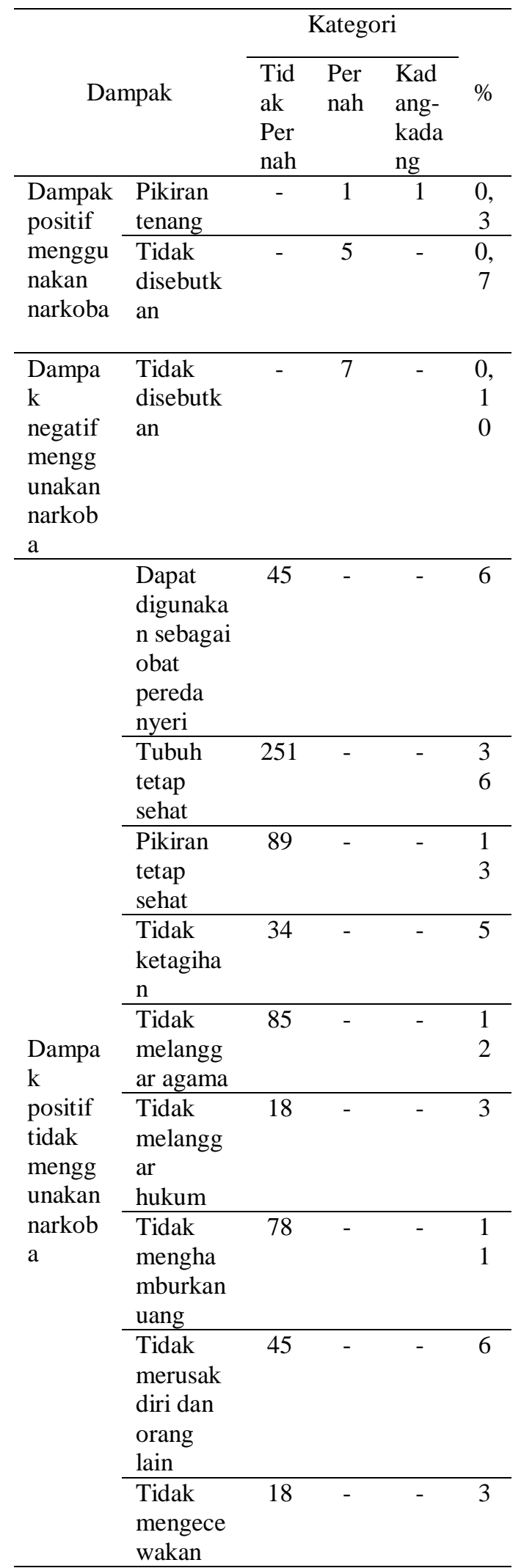




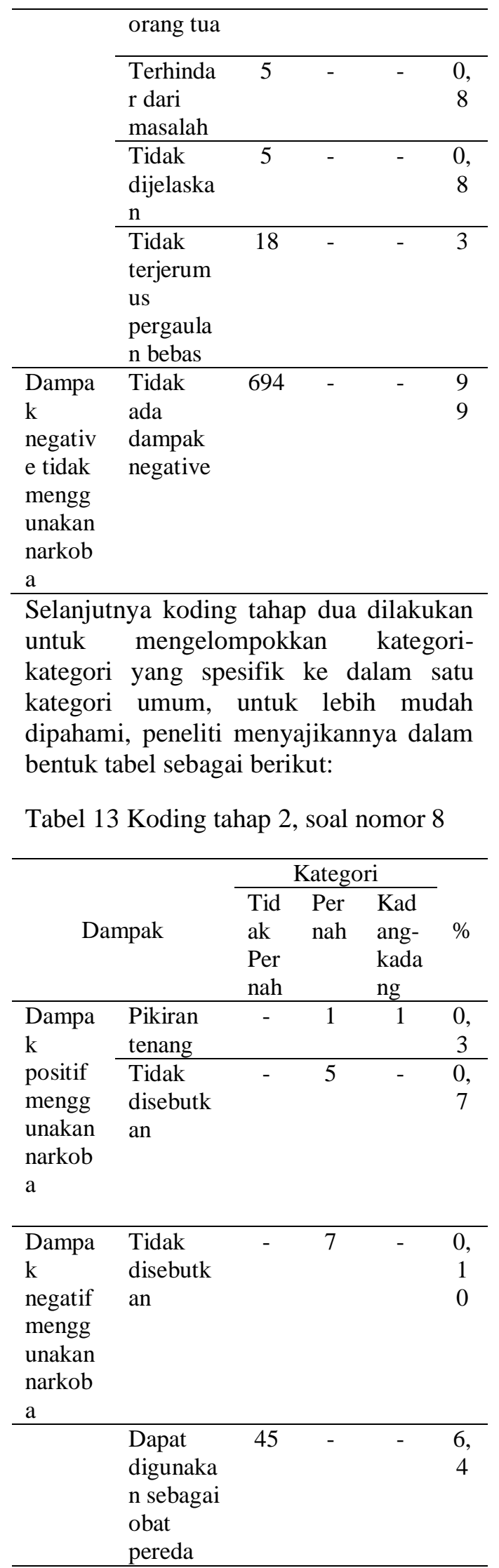

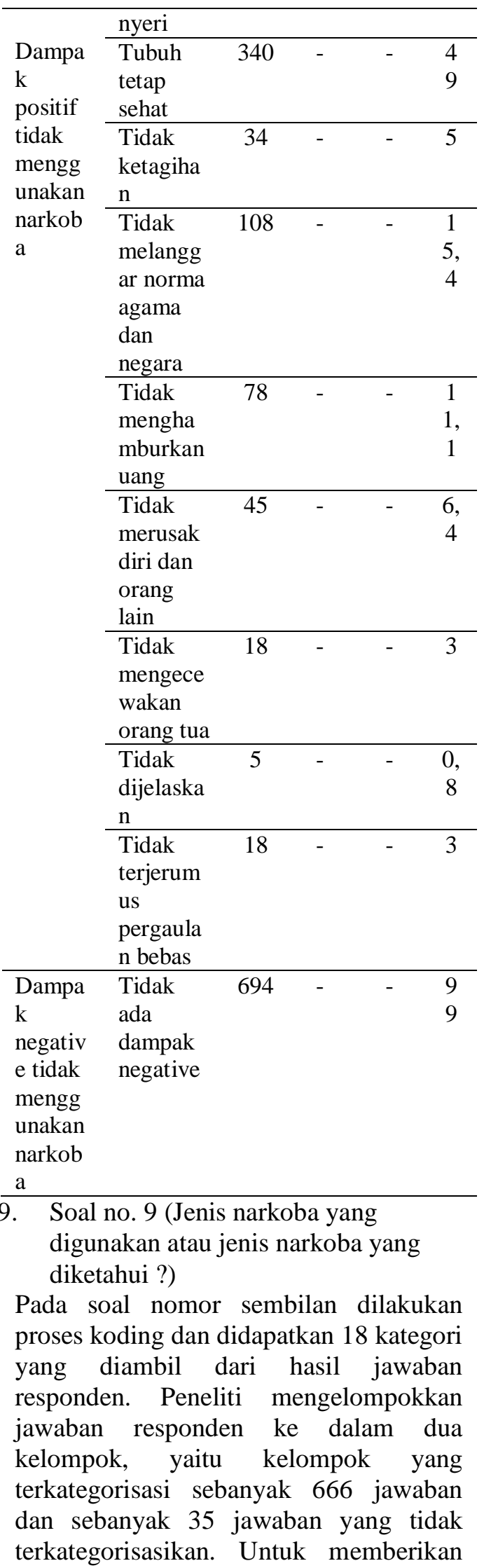


gambaran secara lebih mudah, peneliti menyajikan hasil koding tahap satu dalam bentuk tabel sebagai berikut:

Tabel 14 Koding tahap 1, soal nomor 9

\begin{tabular}{|c|c|c|c|c|}
\hline \multirow{2}{*}{$\begin{array}{c}\text { Jenis } \\
\text { narkoba } \\
\text { yang } \\
\text { diketahu } \\
\text { i }\end{array}$} & \multicolumn{3}{|c|}{ Kategori } & \multirow[b]{2}{*}{$\%$} \\
\hline & $\begin{array}{l}\text { Tidak } \\
\text { Pernah }\end{array}$ & $\begin{array}{l}\text { Perna } \\
\mathrm{h}\end{array}$ & $\begin{array}{l}\text { Kadan } \\
\text { g- } \\
\text { kadan } \\
\text { g }\end{array}$ & \\
\hline Inex & - & 1 & - & 0,1 \\
\hline $\begin{array}{l}\text { Sabu- } \\
\text { sabu }\end{array}$ & - & 1 & - & 0,1 \\
\hline Ganja & - & 2 & - & 0,3 \\
\hline Putaw & - & - & 1 & 0,1 \\
\hline $\begin{array}{l}\text { Tidak } \\
\text { disebutk } \\
\text { an }\end{array}$ & - & 2 & - & 0,3 \\
\hline Inex & 28 & - & - & 4 \\
\hline $\begin{array}{l}\text { Sabu- } \\
\text { sabu }\end{array}$ & 170 & - & - & $\begin{array}{c}24, \\
2\end{array}$ \\
\hline Ganja & 162 & - & - & $\begin{array}{c}23, \\
1\end{array}$ \\
\hline Putaw & 32 & - & - & 4,6 \\
\hline Heroin & 60 & - & - & 8,6 \\
\hline Kokain & 28 & - & - & 4 \\
\hline Dekstro & 10 & - & - & $\overline{1,4}$ \\
\hline Morfin & 32 & - & - & 4,6 \\
\hline Ekstasi & 96 & - & - & $\begin{array}{c}13, \\
7\end{array}$ \\
\hline Opium & 14 & - & - & 2 \\
\hline Nikotin & 22 & - & - & 3,1 \\
\hline Gorilla & 7 & - & - & 1 \\
\hline $\begin{array}{l}\text { Tidak } \\
\text { disebutk } \\
\text { an }\end{array}$ & 33 & - & - & 4,8 \\
\hline & 701 & & 00 & \\
\hline
\end{tabular}

Pada soal nomor sepuluh dilakukan proses koding dan didapatkan 1 kategori yang diambil dari hasil jawaban responden. Peneliti mengelompokkan jawaban responden ke dalam satu kelompok, yaitu kelompok yang terkategorisasi sebanyak 701 jawaban. Untuk memberikan gambaran secara lebih mudah, peneliti menyajikan hasil koding tahap satu dalam bentuk tabel sebagai berikut:

Tabel 15 Koding tahap 1, soal nomor 10

\begin{tabular}{|c|c|c|c|c|c|}
\hline \multirow[b]{2}{*}{$\begin{array}{l}\mathrm{N} \\
\mathrm{O}\end{array}$} & \multirow[b]{2}{*}{$\begin{array}{l}\text { Sedang } \\
\text { menggun } \\
\text { akan } \\
\text { narkoba }\end{array}$} & \multicolumn{3}{|c|}{ Kategori } & \multirow[b]{2}{*}{$\%$} \\
\hline & & $\begin{array}{l}\text { Tida } \\
\mathrm{k} \\
\text { Pern } \\
\text { ah } \\
\end{array}$ & $\begin{array}{l}\text { Pern } \\
\text { ah }\end{array}$ & $\begin{array}{l}\text { Kada } \\
\text { ng- } \\
\text { kada } \\
\text { ng } \\
\end{array}$ & \\
\hline 1 & Tidak & 694 & 6 & 1 & $\begin{array}{c}10 \\
0\end{array}$ \\
\hline To & & & 701 & & $\begin{array}{c}10 \\
0 \\
\end{array}$ \\
\hline
\end{tabular}

\section{Pembahasan}

1. Gambaran mahasiswa/I pernah menggunakan narkoba bahwa mahasiswa/I STIKBA tidak pernah menggunakan narkoba sebesar $99 \%$ dengan responden sebanyak 694 orang

Berdasarkan hasil penelitian diketahui bahwa pengakuan mahasiswa/I mengenai pernah menggunakan narkoba itu beragam, dalam hal ini terdapat 3 kategori yang bisa menggambarkan pengakuan mahasiswa/I STIKBA tentang pernah menggunakan narkoba.

a. Tidak pernah

Kategori tidak pernah menurut mahasiswa/I STIKBA adalah pengakuan mahasiswa/I tidak pernah menggunakan narkoba. Tidak semua remaja/ mahasiswa/i menyalahguna kan atau mencoba narkoba. Beberapa ciri perkem bangan remaja yang rentan terhadap gangguan penggunaan narkotika, psikotropika, alkohol dan zat adiktif lain b. Pernah 
Kategori pernah menurut mahasiswa/I STIKBa adalah pengakuan mahasiswa/I pernah melakukan penyalahgunaan narkoba pada saat masih berstatus SLTA dan saat penelitian jawabannya sudah berhenti menggunakan penyalahgunaan narkoba.

c. Kadang-kadang

Kategori jarang menurut mahasiswa/I STIKBA adalah pengakuan mahasiswa/I jarang melakukan penyalahgunaan narkoba pada saat masih berstatus SLTA dan saat penelitian jawabannya tergantung situasi melakukan penyalahgunaan narkoba.

2. Gambaran alasan menggunakan atau tidak menggunakan narkoba

a. Alasan tidak pernah

Berdasarkan hasil penelitian diketahui bahwa pengakuan mahasiswa/I mengenai alasan tidak pernah menggunakan narkoba itu beragam, dalam hal ini terdapat 3 kategori yang bisa menggambarkan pengakuan mahasiswa/I STIKBA tentang tidak pernah menggunakan narkoba.

1). Berbahaya

Kategori berbahaya menurut mahasiswa/I STIKBA adalah pengguna narkoba bisa menjadi ketergantungan, dapat merusak diri dan orang lain, tidak baik untuk dikonsumsi, merusak mental, sosial dan budaya, serta dapat menghancurkan kehidupan dan kesehatan.

Menurut Ardani, et al. (2007: 232) psikologi kesehatan memberikan perhatian bagaimana perilaku dan pengalaman manusia dapat mempengaruhi kesehatan. Selain itu Ardani, et al. (2007: 230) menambahkan bahwa dasar pemikiran psikologi kesehatan adalah adanya hubungan antara pikiran manusia (mind) dengan tubuhnya. Berdasarkan hal tersebut maka seseorang yang berada dalam kondisi sehat akan memiliki pikiran yang sehat pula, sehingga dengan pikiran yang sehat itu terciptalah kehidupan yang sejahtera.

2). Tidak berguna
Kategori tidak berguna menurut mahasiswa/I STIKBA adalah hanya menghamburkan uang sehingga menimbulkan kerugian.

3). Haram

Kategori haram menurut mahasiswa/I STIKBA adalah aturan agama yang mengharamkan segala jenis barang yang memabukkan seperti narkoba sehingga terganggunya tingkat kesadaran penyalahgunaan narkoba.

b. Pernah

Berdasarkan hasil penelitian diketahui bahwa pengakuan mahasiswa/I mengenai alasan pernah menggunakan narkoba itu karena coba-coba. Penyebab seseorang pertama kali menyalahgunakan narkoba hampir dipastikan karena rasa ingin tahu yang sangat besar, penjelajahan, petualangan, ingin menunjukkan keberanian, ingin ambil risiko, nekat. Masa remaja juga dikenal dengan masa labil, mudah terpengaruh, mudah meniru, tanpa memikirkan akibat di masa datang, BNN (2003). Menurut Landau (dalam Afiatin, 2004b) penyebab terjadinya penyalahgunaan narkoba pada remaja yaitu: gaya hidup keluarga, predisposisi pada alkohol, tekanan kelompok teman sebaya, kekacauan remaja, dan masalahmasalah psikologis dan emosional yang serius.

c. Kadang-kadang

Berdasarkan hasil penelitian diketahui bahwa pengakuan mahasiswa/I menge-nai alasan jarang menggunakan narkoba itu karena pergaulan untuk mengim-bangi kawan.

3. Gambaran dampak menggunakan atau tidak menggunakan narkoba

a. Tidak pernah

Berdasarkan hasil penelitian diketahui bahwa dampak tidak pernah menggunakan narkoba itu menjadi 3 kategori yang bisa menggambarkan pengakuan dampak mahasiswa/I STIKBA tentang tidak pernah menggunakan narkoba yaitu 1). Tetap sehat 
Kategori tetap sehat menurut mahasiswa/I STIKBA adalah tidak sakit fisik, mental yang diakibatkan karena nar-koba, pikiran terkontrol dan bersemangat dalam menjalankan aktivitas.

2) Beruntung

Kategori beruntung menurut mahasiswa/I STIKBA adalah tidak menimbulkan kerugian dari sudut apapun seperti materi, uangnya bisa dipergunakan untuk keperluan kuliah. Lingkungan tetap harmonis tidak bermasalah.

b. Pernah

Kategori ini tidak dijelaskan.

c.Kadang-kadang

Berdasarkan hasil penelitian diketahui bahwa dampak tidak pernah menggunakan narkoba itu menjadi 1 kategori yang bisa menggambarkan pengakuan dampak mahasiswa/I STIKBA tentang jarang menggunakan narkoba yaitu terasa melayang.

4.Keinginan menggunakan narkoba

a. Tidak pernah

Berdasarkan hasil penelitian diketahui bahwa keinginan menggunakan narkoba itu menjadi 1 kategori yang bisa menggambarkan pengakuan mahasis wa/I STIKBA tentang tidak ingin menggunakan narkoba.

Kategori tidak ingin menurut maha siswa/I STIKBA adalah tidak dan tidak akan pernah menggunakan narkoba.

b. Pernah

Berdasarkan hasil penelitian diketahui bahwa keinginan menggunakan narkoba itu menjadi 1 kategori yang bisa menggambarkan pengakuan mahasis wa/I STIKBA tentang sudah berhenti menggunakan narkoba. Kategori sudah berhenti menurut mahasiswa/I STIKBA adalah tidak mau menggunakan narkoba lagi.

c.Kadang-kadang

Berdasarkan hasil penelitian diketahui bahwa keinginan menggunakan narkoba itu menjadi 1 kategori yang bisa menggambarkan pengakuan mahasiswa/I STIKBA tentang tergantung situasi menggunakan narkoba. Kategori tergantung situasi menurut mahasiswa/I STIKBA adalah kondisi mau menggunakan narkoba lagi.

5. Tempat memperoleh narkoba

a. Tidak pernah

Berdasarkan hasil penelitian diketahui bahwa tempat memperoleh narkoba itu menjadi 2 kategori yang bisa menggambarkan pengakuan mahasiswa/I STIKBA tentang tempat memperoleh narkoba yaitu :

1) Tidak tahu

Kategori tidak tahu menurut mahasiswa/I STIKBA adalah tidak mengetahui tempat memperoleh nar-koba.

2) Bandar narkoba

Kategori Bandar narkoba menurut mahasiswa/I STIKBA adalah tempat mendapatkan narkoba.

b. Pernah

Tidak disebutkan tempatnya.

c.Kadang-kadang

Berdasarkan hasil penelitian diketahui bahwa tempat memperoleh narkoba itu menjadi 1 kategori yang bisa menggambarkan pengakuan mahasiswa/I STIKBA tentang tempat memperoleh narkoba yaitu sama teman. Kategori sama teman ini menurut pengakuan penyalahgunaan narkoba adalah narkoba didapatkan dari teman.

6. Cara memperoleh narkoba

a. Tidak pernah

Berdasarkan hasil penelitian diketahui bahwa cara memperoleh narkoba itu menjadi 2 kategori yang bisa menggambarkan pengakuan mahasiswa/I STIKBA tentang cara memperoleh narkoba yaitu :

1). Tidak tahu

Kategori tidak tahu menurut mahasiswa/I STIKBA adalah tidak mengetahui cara memperoleh narkoba.

2) Bandar narkoba

Kategori Bandar narkoba menurut mahasiswa/I STIKBA adalah cara mendapatkan narkoba.

b. Pernah

Tidak disebutkan caranya. 


\section{c.Kadang-kadang}

Berdasarkan hasil penelitian diketahui bahwa cara memperoleh narkoba itu menjadi 1 kategori yang bisa menggambarkan pengakuan mahasiswa/I STIKBA tentang cara memperoleh narkoba yaitu sama teman.

Kategori sama teman ini menurut pengakuan penyalahgunaan narkoba adalah narkoba didapatkan dari teman.

7. Sumber keuangan mahasiswa diperoleh dipergunakan untuk narkoba atau tidak digunakan untuk narkoba

a. Tidak pernah

Berdasarkan hasil penelitian diketahui bahwa sumber keuangan untuk memperoleh narkoba atau tidak digunakan untuk narkoba itu menjadi 1 kategori yang bisa menggambarkan pengakuan mahasiswa/I STIKBA tentang sumber keuangan yaitu dari orang tua dan tidak bersedia untuk mendapatkan narkoba:

b. Pernah

Berdasarkan hasil penelitian diketahui bahwa sumber keuangan untuk memperoleh narkoba atau tidak digunakan untuk narkoba itu menjadi 2 kategori yaitu Tidak disebutkan sumbernya dan teman dari teman.

\section{c.Kadang-kadang}

Berdasarkan hasil penelitian diketahui bahwa sumber memperoleh narkoba itu menjadi 1 kategori yang bisa menggambarkan pengakuan mahasiswa/I STIKBA tentang sumber keuangan memperoleh narkoba yaitu tidak berpenghasilan yang hanya didapat dari teman.Kategori sama teman ini menurut pengakuan penyalahgunaan narkoba adalah narkoba didapatkan dari teman.

8. Dampak positif dan negative menggunakan narkoba atau tidak menggunakan narkoba

\section{a. Tidak pernah}

Berdasarkan hasil penelitian diketahui bahwa dampak positif tidak menggunakan narkoba itu tubuh tetap sehat, tidak melanggar agama dan Negara, tidak menghamburkan uang dapat digunakan sebagai obat pereda nyeri, tidak merusak diri dan orang lain, tidak ketagihan, tidak meengecewakan orang tua, tidak terjerumus pergaulan bebas.

b. Pernah

Berdasarkan hasil penelitian diketahui bahwa dampak positif tidak menggunakan narkoba itu menjadi 2 kategori yaitu Tidak disebutkan sumbernya dan pikiran tenang.

c. Kadang-kadang

Berdasarkan hasil penelitian diketahui bahwa sumber memperoleh narkoba itu menjadi 1 kategori yang bisa menggambarkan pengakuan mahasiswa/I STIKBA tentang sumber keuangan memperoleh narkoba yaitu tidak berpenghasilan yang hanya didapat dari teman. Kategori sama teman ini menurut pengakuan penyalahgunaan narkoba adalah narkoba didapatkan dari teman.

9. Jenis narkoba yang digunakan atau jenis narkoba yang diketahui

a. Tidak pernah

Berdasarkan hasil penelitian diketahui bahwa jenis narkoba yang diketahui yaitu sabu-sabu, ganja, ekstasi, heroin, putaw, morfin, inex, kokain, nikotin, opium, dekstro, gorilla dan tidak disebutkan.

b. Pernah

Berdasarkan hasil penelitian diketahui bahwa jenis narkoba yang pernah digunakan ganja, inex, sabu-sabu.

c. Kadang-kadang

Berdasarkan hasil penelitian diketahui bahwa jenis narkoba yang pernah digunakan adalah putaw.

10.Apakah sedang menggunakan narkoba Berdasarkan hasil penelitian diketahui bahwa semua mahasiswa/I berdasarkan pengakuan semuanya tidak sedang menggunakan narkoba.

\section{SIMPULAN}

Gambaran mahasiswa/I STIKBA pernah menggunakan narkoba bahwa mahasiswa/I STIKBA tidak pernah 
menggunakan narkoba sebesar $99 \%$ dengan responden sebanyak 694 orang

\section{SARAN}

Hal yang bisa dilakukan untuk meminimalisir mahasiswa/i dalam penyalahgunaan NAPZA sebagai berikut:

1. Membangkitkan kesadaran beragama, mencari informasi dan hal-hal yang positif dan bermanfaat

2. Selektif dalam memilih teman

3. Menghindarkan diri dari lingkungan yang tidak tepat

4. Menanamkan pendidikan agama sejak dini

5. Mencari tahu fakta-fakta tentang narkoba termasuk akibat-akibat yang akan ditimbulkan apabila mengkonsumsi barang haram tersebut.

6. Menciptakan kehidupan beragama di dalam berumah tangga dan menciptakan suasana kasih sayang antara kedua orang tua dan anak.

7. Bekerjasama dalam menghadapi sindikat pengedar NAPZA, serta berani melaporkan ke aparat apabila melihat sinyalemen adanya pengedar pengedar atau pengguna di sekitar kita.

8. Diharapkan peran orang tua untuk lebih mengawasi dan membimbing anggota keluarganya, serta lebih meluangkan waktunya untuk selalu berada disisi anak-anaknya dalam kondisi apapun, sehingga remaja tidak terjerumus melakukan hal- hal yang menyimpang terutama melakukan penyalahgunaan narkoba.

9. Masyarakat hendaknya melakukan kegiatan yang positif dan berguna agar remaja tidak terlibat dalam kasus penyalahgunaan narkoba serta memperdalam iman dan taqwa guna ketahanan diri dalam menghadapi dan memecahkan permasalahan hidup.
10. Diharapkan pihak BNN lebih meningkatkan pengawasan dan menindak tegas para pelaku kejahatan narkoba yang dapat merusak generasi bangsa, serta lebih meningkatkan pemahamanpemahaman kepada masyarakat akan bahaya penyalahgunaan narkoba.

\section{DAFTAR PUSTAKA}

1. Arikunto, Suharsini. 2006. Prosedur Penelitian Suatu Pendekatan Praktik Jakarta, Rineka Cipta.

2. Alifia, U, 2008. Apa Itu Narkotika dan Napza. PT Bengawan Ilmu, Semarang.

3. BNN-RI 2009"advokasi pencegahan penyalahgunaan narkoba,

4. Budianto. 1989. Narkoba dan Pengaruhnya. Ganeca Exact. Bandung

5. Darman, Flavianus. Mengenal Jenis dan Efek Buruk Narkoba. Visimedia, Jakarta. 2006.

6. Kartini Kartono. 1992. Patologi Sosial 2. Kenakalan Remaja. Rajawali Press, Jakarta

7. Libertus Jehani \& Antoro dkk. 2006. Mencegah Terjerumus Narkoba. Visimedia. Jakarta

8. Moh. Taufik Makaro, Suhasril dan Moh. Zakky. 2005. Tindak Pidana Narkotika.

Ghalia Indonesia. Bogor.

9. Soekanto, Soejono. 2009. Sosiologi Suatu Pengantar. Jakarta. PT. Raja Grafindo Persada.

10. Siahaan, Jokie. 2009. Perilaku Menyimpang Pendekatan Sosiologi. Jakarta. PT Indeks.

11. Silalahi, Ulber. 2010. Metode Penelitian Sosial. Jakarta. Refika Aditama. 
12. Sadhi Astuti,Made. 2003. Hukum Pidana Anak dan Perlindungan Anak. Malang. Universitas Negeri Malang

13. Sugiyono. (2010). Metode

Penelitian Kuantitatif, Kualitatif, dan $R \& D$.Cetakan ke-17.

Bandung. Alfabeta.

14. Soetomo. 2013. Masalah Sosial dan Upaya Pemecahannya. Yogyakarta. Pustaka Pelajar.

15. Umar, Husain. 2002. Metode Riset Komunikasi dan Organisasi. Jakarta. PT.Gramedia. 